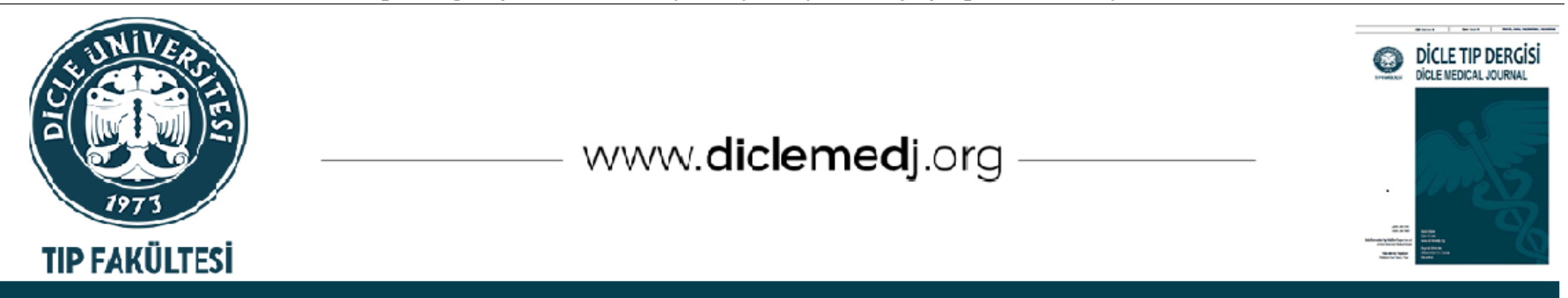

Derleme / Review

\title{
COVID-19 Tedavisinde Terapötikler
}

\section{Gökhan Kırbaş 1}

1 Dicle Üniversitesi Tıp Fakültesi. Göğüs Hastalıkları AD. Diyarbakır, Türkiye

Geliş: 29.09.2021; Kabul Tarihi: 29.09.2021

Öz

COVID-19 pandemisi üzerinden nerede ise iki yıl geçmiş olmasına rağmen hala etkili bir tedavi geliştirilememiştir. Uygulanan tedavilerin çoğu daha önceki viral hastalık pandemilerinden elde edilen verilere dayanmaktadır. Covid-19 tedavisi için denenen veya geliştirilen antiviral ve immünsistem düzenleyici tedavilerin uygun kombinasyonlarının denenmesi, daha etkin ilaçların keşfi gibi gelişmeler yol gösterici olacaktır.

Anahtar kelimeler: Koronavirüs hastalığı 2019 (COVID-19), tedavi, terapötikler.

\section{Therapeutics in The Treatment of COVID-19}

\begin{abstract}
Although almost two years have passed since the COVID-19 pandemia, an effective treatment has not been developed yet. Most of the treatments applied are based on data from previous viral disease pandemics. Developments such as the trial of appropriate combinations of antiviral and immunomodulatory therapies that have been tried or developed for the treatment of disease, and the discovery of more effective drugs will be guiding.
\end{abstract}

Keywords: Coronavirus disease 2019 (COVID-19), treatment, therapeutics.

DOI: 10.5798/dicletip.1005424

Yazışma Adresi / Correspondence: Gökhan Kırbaş, Dicle Üniversitesi Tıp Fakültesi. Göğüs Hastalıkları AD. 21280 Diyarbakır, Türkiye email: gkirbas@yahoo.com 


\section{GíRiş}

Aralık 2019 da tespit edildiğinden bu yana COVID-19'un etkin tedavisi için çok sayıda farmakolojik ajan denenmiştir. Maalesef bu ajanların hiçbirinin gerçekten etkili olduğu henüz kanıtlanmamıştır; ayrıca, belirli bir antiviral ilaç sağlık yetkilileri tarafından ruhsatlanmamıștır. Hasta yönetimi, destekleyici tedavi ile klinik semptomları azaltmaya yönelik yaklaşımdan ibarettir. Bu derleme COVID-19 Tanı ve Tedavisinde Kanıta Dayalı Öneriler ve Türk Toraks Derneği COVID-19 Görev Grubu Görüş Raporu1, Akciğer Sağlı̆̆ı ve Yoğun Bakım Derneği (ASYOD), Güncel Göğüs Hastalıkları Serisi Kitapları, Viral Pnömoniler ${ }^{2}$ ve T.C. Sağlık Bakanlığının COVID-19 (SARS-CoV-2 Enfeksiyonu) Erişkin Hasta Tedavisi ${ }^{3}$, Antisitokin-Antiinflamatuar Tedaviler, Koagülopati Yönetimi ${ }^{4}$ ve COVID-19 İmmün (Konvalesan) Plazma Tedarik ve Klinik Kullanımı $^{5}$ rehberlerine göre, güncel literatürler ile yeniden gözden geçirilerek hazırlanmıştır. Bu derlemenin içinde yer yer tedavi protokolleri yer alsa da derlemenin amacı COVID-19 tedavisini algoritmik bir şekilde vermek değil, pandeminin başından bu yana kullanılan önemli kemoterapi ajanlarını ve tedavi stratejilerini gösterebilmektir.

COVID-19 tedavisinde kullanılan terapötikler potansiyel rollerine göre gruplandırılabilirler; viral pnömoninin tedavisinde antiviral ve antiviral/immünmodülatörler, sitokin fırtınası ve makrofaj aktivasyon sendromu (MAS) tedavisinde anti-sitokinler, JAK inhibitörleri ve diğer antiinflamatuvar ilaçlar, ARDS tedavisinde antiinflamatuvar ilaçlar, koagulopati tedavinde; antikoagülan ve antiagregan ilaçlar'6.

Hidroksiklorokin/Klorokin: Otoimmün hastalıklar ve malarya tedavisinde kullanılan klorokin ve hidroksiklorokin, geç endozomal ve lizozomal pH'yı artırarak fonksiyon gören lizozomtropik ajanlardır. COVID-19 pandemisinin başlangıcında antiviral ve immünomodülatör etkili olduğu düşünüldüyse de güncel çalışmalar Hidroksiklorokin'in klinik iyileşmeyi hızlandırmadığını, ölüm oranlarını düşürmediğini göstermiştir. Buna karşıllk, Hidroksiklorokin ve klorokin kardiyotoksiktir. QT aralığında uzama, ventilatör taşikardi, ventriküler fibrilasyon yapabilir ${ }^{2}$. Hidroksiklorokinin - azitromisin kombinasyonu klinik yarar sağlamaz ${ }^{7}$.

İvermektin: Geniş sprektrumlu FDA onaylı bir antiparaziterdir. İn vitro olarak hücre kültüründe SARS-CoV-2'yi 48 saat içerisinde 5000 kat (viral RNA) azaltarak etkili olduğu gösterilmiş, ancak bunun tam olarak nasıl gerçekleștirildiği anlaşlamamıştır. Bu etkinin muhtemelen antiviral proteinlerin nükleusa geçişindeki bir inhibisyonu üzerinde olduğu varsayılmaktadır ${ }^{2}$.

2021 yılı içerisinde tüm dünyada İvermektin ile ilgili çok sayıda çalışma yapılmışıtır. Bryant ve arkadaşlarının metaanalizinde "Orta kesinlikte kanitlarla, İvermektinin COVID-19 ölümlerinde büyük düşüşe yol açtığı ve erken evrede kullanımının ağır hastalığa progresyonu azalttığı gösterilmiştir. Aynı şekilde güvenilirliği ve düşük maliyeti, ivermektinin küresel olarak SARS-CoV-2 pandemisi üzerinde önemli bir terapötik ajan olacağını gösteriyor" denilmektedir ${ }^{8}$.

Real-time online (27 Eylül 2021 tarihinde) olan makalede ivermektinin COVID-9 hastalarında kullanımının viral klirensi azaltma, ayaktan takipde iyileşme, hastaneye yatış, yoğun bakım ünitesine kabul, ventilasyona bağlanma ve mortalite için istatistiksel olarak anlamlı iyileşme yaptığ bildirilmiş ${ }^{9}$. Mevcut bu çalışmalar İvermektinin COVID-19 tedavisinde 
umut vaat ettiğini ve bir süre sonra tedavi rehberlerine girebileceğini düşündürmektedir.

Favipiravir: Bir RNA polimeraz inhibitörüdür. Favipiravir, Ebola, influenza ve SARS-CoV-2 enfeksiyonunda da kullanılmıştır. Buna karşılık Favipiravirin'in COVID-19'da etkin olduğunu gösteren, kanıt düzeyi yüksek bir çalışma henüz yayınlanmamıştır. Sağlık Bakanlığının COVID19 erişkin hasta tedavisi rehberinde Favipiravir'in dozu, ayaktan izlenecek komplike olmayan veya yatış endikasyonu olup da komplike olmayan hastalarda ; $200 \mathrm{mg}$ tablet, 2 x 1600 mg yükleme, 2 x 600 mg idame, 5 gün olarak önerilmektedir. Hafif-orta veya ağır seyirli pnömonili olgularda ise aynı dozda ama daha uzun süre ile, 10 güne kadar kullanımı önerilmektedir.

Favipiravirin COVID-19 tedavisinde veya diğer endikasyonlarla kullanımı sırasında ciddi istenmeyen etkileri tanımlanmamıș, en sık tanımlanmış istenmeyen etkileri ise hiperürisemi, karaciğer enzimlerinde yükseklik ve ishal olmuştur ${ }^{10}$. Favipiravir influenzaya karşı da etkili olması nedeniyle, grip sezonunda birbiriyle karıșabilecek COVID-19 ve grip hastalarının tek ajanla tedavi edilmesine olanak tanıyabilir.

Oseltamivir: Oseltamivir bir nöraminidaz inhibitörüdür. 2010 influenza H1N1 salgını sırasında başarıyla kullanılmıştır. SARS-CoV-2 pandemisinin başında oseltamivir birçok hastada kullanılmış, ancak son klinik çalışmalarda anlamlı bir etkinliği gösterilememiştir.

Lopinavir/Ritonavir: Lopinavir/ritonavir, HIV enfeksiyonlarının tedavisi için onaylanmış oral bir proteaz inhibitörüdür. Lopinavir, ritonavir ile birlikte kullanılır, ritonavir lopinavirin yarılanma ömrünü uzatır. SARS-CoV-2 ye karşı SARS ve MERS deki kadar etkin değildir ${ }^{11}$.

Remdesivir: Remdesivir (GS-5734) viral RNA polimerazlarını inhibe eden bir nükleotid analoğu olan bir ön ilaçtır. SARS-CoV, MERSCoV ve SARS-CoV-2'ye oldukça düşük konsantrasyonda etkili bulunmuşdur. RNA replikasyon mekanizmasını kodlayan genlerdeki mutasyonlar nedeni ile tedaviye dirençli suşların ortaya çıkışını azaltmak için ribavirin ile remdesivirin beraber kullanımının yararlı olacağı söylenmektedir ${ }^{12}$. Eldeki veriler remdesivir'in rutin kullanımını önermek için yetersizdir. Sadece intravenöz formu bulunan remdesivir ülkemizde ruhsatlı değildir. Sağlık Bakanlığ'ında sınırlı sayıda bulunan bu ajan ağır COVID-19 hastalarında, endikasyon dişı ilaç başvurusu yapılarak onay verilmesi halinde kullanılabilmektedir. Remdesivir COVID-19 hastalarında kullanımı sırasında ciddi istenmeyen etkisi bildirilmemiş, en sık bildirilen istenmeyen etkisi ise karaciğer fonksiyon testlerinde bozulma olmuştur ${ }^{1}$.

Molnupiravir: Gelecek vadeden yeni bir antiviraldir. Molnupiravir, cytidine adlı doğal bir nükleozid molekülü analoğudur. RNA virüsleri tarafından RNA zincirini oluşturmak için kullanılır. Molnupiravir bulunan ortamda virüs, cytidine yerine molnupiravire yönelir böylece RNA zincirinin oluşumunda hataya yol açar. Hatalı RNA içeren virüs hücreleri enfekte edemez. Molnupiravirinin faz 3 çalışmaları pek çok merkezde devam etmektedir. COVID-19 tedavisinde muhtemel, etkili bir ajandır ${ }^{13}$.

Salgının başlamasının üzerinden neredeyse iki yıl geçmesine rağmen COVID-19'a karşı etkinliği kesin olarak gösterilmiş bir anti-viral tedavi halen yoktur ve tedavinin esasını optimal bir destek tedavisi oluşturmaktadır. COVID-19 genellikle hafif-orta seyirli bir hastalık olmakla birlikte, olguların yaklaşık \%10-15'inde ağır seyredebilmektedir. \%0,6-1 arasında olduğu hesaplanan infeksiyon ölüm oranıyla, bu oranın $<\% 0,1$ olduğu gripten en az 5-10 kat daha ölümcül bir infeksiyon hastalığıdır. $\mathrm{Bu}$ nedenlerle etkili bir anti-viral tedavisinin bulunması tüm bilim dünyasının en büyük önceliğidir ve halen bu konuda çok sayıda klinik araştırma devam etmektedir. Veriler, herhangi 
bir antiviralin tüm COVID-19 hastalarının tedavisinde önerilebilmesi için yeterli kanıt sağlayamamaktadır ${ }^{1}$.

Antibiyotikler: COVID-19 olgularında eşzamanlı ya da sekonder bakteriyel enfeksiyon görülme sıklığı \%0-6 ile \%3-8 olarak bildirilmiştir ${ }^{14}$. SARS-CoV-2 enfeksiyonuna bakteriyel (Staphylococcus aureus, Streptococcus pneumoniae, Hemophilus influenzae, Mycoplasma pneumoniae, Chlamydia pneumoniae) ya da fungal (Candida species, Aspergillus flavus, Mucormycosis) etkenler eşlik edebilmektedir.

COVID-19' da antibiyotiklerin rutin tedavide kulanılmasına ilişkin bilimsel veri yayınlanmamıştır. Amerikada NIH ve Dünya Sağlık Örgütü, hafif-orta COVID-19 olgularında bakteriyel enfeksiyona dair klinik şüphe olmadıkça profilaktik antibiyotik kullanımını önermemektedir ${ }^{15,16}$. Akılcı bir yaklaşımla, klinik olarak bakteriyel ko-enfeksiyondan kuşkulanılan olgularda tedaviye antibiyotik eklenebilir ${ }^{17}$.

Konvalesan (immün) plazma tedavisi: Konvalesan (immün) plazma tedavisi, COVID19 geçirip, iyileşen hastalardan alınan antikordan zengin plazmanın işlenerek hasta kişilere verilmesi, böylece pasif immünizasyonun sağlanmasıdır. COVID-19 da immün yanıt, hümoral immünite üzerinden gelişir. Anti-SARS-CoV-2 antikorları semptom sonrası ortalama 13. günde tespit edilirken, nötralizan antikorların pik yapması 23. güne dek uzayabilir. Antikorlar, direkt viral etki ile virüsleri nötralize eder ve indirekt etki ile de komplemen kaskadını, fagositozu ve hücresel sitotoksisiteyi uyarırlar ${ }^{18}$. Sağlık Bakanlığının rehberine göre COVID-19 tanısı olan hastalarda semptomların başlamasından sonra en geç 7 gün içerisinde ve sitokin fırtınasının ön plana çıktığı bulgularda kullanılması önerilmemektedir.
Sitokin firtınası ise; tedaviye rağmen devam eden dirençli ateş, devamlı yüksek seyreden ya da artmaya devam eden CRP ve ferritin değerleri, D-dimer yüksekliği, lenfopeni ve trombositopeni, karaciğer fonksiyon testlerinde bozulma, hipofibrinojenemi veya trigliserid değerlerinde yükselme olarak tanımlanmaktadır 5 . Bu beklentilere rağmen hastaneye yatarak tedavi gören COVID -19 hastalarında konvalesan plazma tedavisinin hayatta kalmaya faydası gösterilememiștir ${ }^{19,20}$. Bununla birlikte Ocak 2021 tarihinde New England Journal of Medicine (NEJM)'da yayınlanan çalışmaya da 65 yaş üstü, COVID-19 enfeksiyonuna bağlı hafif semptomların ilk 72 saatinde olan hastalara yüksek titrede konvalesan plazma verilmiş ciddi respiratuvar hastalık gelişme oranında placeboya göre \%48 azalma saptanmıştır. Araştırmacılar, sonuç olarak aşı yaygınlaşana kadar riskli hastalarda erken konvalesan plazma uygulaması iyileşme için köprü oluşturabilir yorumu yapmışlardır ${ }^{21}$.

Ekim 2020 T.C. Sağlık Bakanlığ. COVID-19 İmmün (Konvalesan) Plazma Tedarik ve Klinik Kullanımı rehberine göre konvalesan plazma endikasyonları şöyledir ${ }^{5}$. Hastanın semptomlarının başlamasından sonra geçen sürenin 7 günü aşmamış olması ve 60 yaş üzerinde olması veya 18-60 yaş arasında olup kanser, KOAH, kardiyovasküler hastalık, hipertansiyon, DM gibi ciddi komorbiditelerin bulunması veya 18-60 yaş arasında olup bağışıklık sistemini baskılayan ilaç kullanması / bağışı sistemini baskılayan hastalığı bulunması. pnömoni bulgularının olmaması, yoğun bakım ihtiyacı olmaması greklidir.

Literatürde konvalesan plazmanın profilaktik olarak kullanımı ile ilgili bir veri ve öneri mevcut değildir ${ }^{21}$. Konvalesan plazmanın yoğun bakıma gidişi engellemek için verilmesinin doğru olmadığı olmadığı gösterilmiştir ${ }^{19}$. Antikorların viral girişi teşvik ederek ya da Fc $\gamma$ reseptör uyarımı ile proinflamatuvar mekanizmalar yoluyla hastalığı hızlandırarak 
"antibody-dependent enhancement (ADE)" a neden olabilirler. Teorik olarak ADE, SARS-CoV2'ye özel nötralizan antikor bakılmadan transfüze edilen konvalesan plazmalarda, nonnötralizan antikorların varlığına ya da nötralizan antikor düzeyinin düşük olmasına ikincil viral antijenlerin bloke edilememesine bağlı olarak gelişir. Dahası, pasif antikor transfüzyonu, alıcının hümoral immünitesinin baskılanmasına ve hastanın enfeksiyona yatkın hale gelmesine neden olabilir ${ }^{1,23}$.

Mezenkimal kök hücre tedavisi (MKH): MKH, immünmodülatör ve rejenerasyonu tetikleyebilen multipotent stromal hücrelerdir. Sitokin fırtınasının önlenebilmesi için kullanılmıştır. Literatürde $\mathrm{MKH}$ tedavisi etkinliği için sınırlı veri bulunmaktadır ${ }^{1}$.

İntravenöz immünglobulin (IVIG): IVIG binlerce sağlıklı vericiden alınan plazmaların havuzlanması ile elde edilen, saflaştırılmış poliklonal IgG ürünleridir. İmmünmodülatör etkileri sayesinde birçok otoimmün ve sistemik inflamatuar hastalı̆̆ın tedavisinde yaygın olarak kullanılmaktadır. IVIG, 2012 ve 2015 yıllarındaki MERS CoV pandemilerinde kullanılmıștır. $\mathrm{Bu}$ nedenle, COVID-19 seyri sırasında da karşılaşılabilecek olası endikasyonlarında kullanımı söz konusu olabilir. IVIG tromboza yol açabilir. Özellikle COVID-19'un patogenezindeki mikrovasküler tromboz eğilimi dikkate alındığında, IVIG uygulamalarının antikoagülan tedaviyle birlikte yapılması tercih edilmelidir. COVID-19 tedavisinde IVIG rutin kullanımını destekler yeterli klinik çalışma bulunmamaktadır ${ }^{1}$.

Kortikosteroid tedavisi: COVID-19 pandemisi başlarında steroid tedavisinin kullanımı, viral eneksiyonlarda ki olumsuz sonuçları nedeniyle önerilmemişti. Ancak radomize kontrollü açık etiketli tasarlanmış olan RECOVERY çalışmasında 10 güne kadar $6 \mathrm{mg} /$ gün deksametazonun etkisi değerlendirilmiştir. Bu çalışmada deksametazon tedavisinin oksijen desteği alan ve mekanik ventilasyon desteği alan hastalarda mortaliteyi azalttığ 1 ancak solunum desteği almayan hastalarda mortalite üzerine etkisinin olmadığı gözlenmiştir. $\mathrm{Bu}$ çalışma sonrasında, deksametazon, COVID-19 hastalarında ölüm oranını düşürdüğü kanıtlanmış tek ilaç olmuştur. Ancak bu olumlu etki yalnızca ağır seyirli COVID-19 vakalarında geçerlidir ${ }^{2,23}$.

Sağlık Bakanlığı da RECOVERY çalışmasına dayanarak, solunum sıkıntısı nedeniyle oksijen tedavisi desteği ihtiyacl olan hastalarda $6 \mathrm{mg} /$ gün deksametazon veya $0.5-1 \mathrm{mg} / \mathrm{kg}$ prednisolon veya eşdeğeri metilprednisolon 10 gün kadar kullanılmasını önermiștir. Buna rağmen 24 saat içinde oksijen ihtiyacı artan veya akut faz yanıtı artan hastalarda, daha yüksek dozda glukokortikoid (pulse, $\geq 250$ $\mathrm{mg} /$ gün metil prednizolon) verilmesine karar verilebilir. Yüksek doz glukokortikoid tedavisi vaka bazında, bazı durumlarda sorumlu hekimin ve/veya romatoloji uzmanının önerisi ile 3 güne kadar kullanılabilir. Yüksek doz steroid uygulaması sonrasında $6 \mathrm{mg} / \mathrm{gün}$ deksametazon veya $0.5-1 \mathrm{mg} / \mathrm{kg}$ prednisolon veya eșdeğeri metilprednisolon ile tedaviye devam edilmelidir. En az 3 gün süreyle kullanılan glukokortikoidlere rağmen hızlı ilerleyen ciddi MAS tablolarında anti-sitokin ilaçların kullanılması düşünülmelidir4.

Hastalığın viral fazı olan ilk 5-7 gün içerisinde kortikosteroid uygulamasının yararlı olmadığı düşünülmektedir. RECOVERY çalışmasında oksijen ihtiyacı olmayan hastalarda steroid tedavisinin zararlı olabileceğini, düşük doz deksametazonun orta ila şiddetli COVID-19 hastalarında yararlı olabileceğini göstermiştir ${ }^{1}$. RECOVERY çalışmasında gebeler için prednizolon $40 \mathrm{mg}$ /gün tablet, oral alamayanlar için ise günde $2 \mathrm{kez} 80 \mathrm{mg}$ IV hidrokortizon önerilmiştir. Bunun sebebi prednizolon ve hidrokortizonun büyük oranda plasenta tarafindan metabolize ediliyor ve dekzametazonun ise plasentadan geçebiliyor olmasidir ${ }^{23}$. 
COVID-19 pnömonisi sonrası hastaların küçük bir kısmında değișen oranlarda radyolojik olarak akciğer fibrozisi ile uyumlu olan ve/veya yaygın ve yoğun buzlu cam dansiteli alanların ön planda olduğu radyolojiye sahip, aylarca CPAP ya da yüksek akımlı oksijen tedavisinden ayrılamayan ve bir kısmı entübe edilip sonrasında pnömomediastinum, ve/veya pnömotoraks ve sepsis gelişip genellikle kaybedilen hasta grubuna dair mevcut literatürde herhangi bir veri maalesef mevcut değildir ${ }^{1}$.

İnhaler kortikosteroidler: Pandeminin başlangıcında alerjisi, astımı veya KOAH'ı olan bireylerin COVID-19 için riskli grupta olabileceği düşünülmüş olmasına rağmen pandemi sırasında yayınlanan pek çok çalışmada bu hastaların risk grubunda olmadığı görülmüștür ${ }^{25}$.

KOAH'ta da inhaler kortikosteroidlerin (IKS) SARS-CoV-2 giriș reseptörü ACE-2'leri azalttığı bilinmektedir. IKS kullananlarda COVID-19 mortalitesinin düştüğü gösterilmiş, COVID-19 için koruyucu olacağı düşünülmüştür. Astım allerji uzlaşı raporu GINA da allerjik rinit ve astım hastalarına tedaviye devam etmelerini önemle vurgulamaktadır. Geleneksel astım tedavisi mutlaka IKS, içerir ve antiviral savunmayı artırarak ve inflamasyonu hafifleterek astımlıların koronavirüs enfeksiyonu risklerini azaltabilir ${ }^{26}$.

IL-1, IL-6 ve TNF- $\alpha$ Anti-sitokin monoklonal antikor kullanımı: COVID-19 olgularının ekserisi enfeksiyonu semptomsuz ya da hafiforta şiddette atlatırken, bir kısmında ağır pnömoniyle beraber sitokin firtınası, multi organ yetmezliği ve dissemine intravasküler koagülopati gelişmektedir. Sitokin fırtınası; immünopatolojik bir etkiye yol açarak ekstravazal kaçağa, koagülopatiye, farklı organlarda yetersizliğe ve sonuç olarak ölüme neden olmaktadır. Sitokin firtınasından sorumlu sitokinler; interlökin (IL)-1, IL-6, IL-8, tümör nekrozis faktör (TNF)- $\alpha$, çok sayıda proinflamatuvar kemokin ve interferon (IFN)- $\gamma$ 'lar olarak siralanabilir ${ }^{1}$. Bu nedenle sitokinleri baskllamak COVID-19 tedavisinde ana hedeflerden biri haline gelmiştir.

Tosilizumab: Tosilizumab, İnterlökin-6 reseptörüne karşı bir monoklonal antikordur. Membrana bağlı ve çözünür haldeki IL-6 reseptörüne bağlanarak IL- 6'nın bu reseptörlere bağlanmasına engel olur. Tosilizumab COVID-19 da ölüm oranlarını düşürür ve mekanik ventilasyon ihtiyacını azaltır. Tosilizumab tedavisine kortikosteroid eklenmesi yoğun bakıma yatış ve mortalite riskini azaltır. Tosilizumab'ın IL-6'nın "koagülasyon kaskat aktivator plazminojen aktivator inhibitor-1 (PAI-1)”yolu ile ortaya çıkan endotelyal hücre zararını engeller ${ }^{26}$. Tosilizumab ile birlikte Janus kinaz/sinyal dönüştürücü ve trankripsiyon aktivatör inhibitörü (JAK-STAT) olan ruksolitinib kullanımının ateş, D-dimer, CRP, ferritin düzeylerini düşürdüğü bildirilmiştir ${ }^{1}$.

COVID-19 da hiperinflamatuvar yanıta bağlı sitokin firtınası ile karakterize makrofaj aktivasyonu sendromu (MAS) ya da başka bir ifade ile edinsel (sekonder) hemofagositik lenfohistiyositozis (sHLH) bulgularının gelişebildiği bilinmektedir. Sağlık Bakanlığı göre, MAS gelişiminde glukokortikoidler yetersizse, endikasyon dışı ilaç talebi ile tosilizumab ya da anakinra kullanılabilir" .

MAS tanısı için yardımcı bulgular; devam eden dirençli ateş, devamlı yüksek seyreden ya da artmaya devam eden CRP, normalin üst sinırlarının üzerinde olan ve artmaya devam eden ferritin değerleri ( $>700 \mu \mathrm{g} / \mathrm{L}$ ), D-dimer yüksekliği, lenfopeni, trombositopeni, nötrofili ve karaciğer fonksiyon testlerinde (ALT, AST, LDH) bozulmadır. Hipofibrinojenemi geç dönemde görülebilir. Trigliserid artışı ve organomegali ise saptanmayabilir. Prokalsitonin ile sekonder enfeksiyon olmadığı gösterilmeli ${ }^{4}$. 
T.C. Sağlık Bakanlığı AntisitokinAntiinflamatuar Tedaviler, Koagülopati Yönetimi rehberine göre; MAS bulguları gelişmiş olan ve glukokortikoid tedaviye yanıt alınamayan ya da hızlı ilerleyen MAS bulguları olan hastalarda tosilizumab $8 \mathrm{mg} / \mathrm{kg}$ dozunda (en fazla $800 \mathrm{mg}$ ) uygulanabilir. Hastadaki bulguların ciddiyetine göre bir seferde $400 \mathrm{mg}$ ya da $800 \mathrm{mg}$ IV olarak verilebilir. İlk doz 400 mg olarak yapıldığında, klinik ve laboratuvar bulgularındaki değerlerdeki değişimler göz önüne alınarak 24 saat içinde 200-400 mg şeklinde doz tekrarı yapılabilir. Nihai volüm 100 cc olacak şekilde izotonik sodyum klorür $(\% 0,9)$ içerisine eklenerek 1 saatte intravenöz infüzyon yoluyla uygulanması önerilmiştir. İlk doz $400 \mathrm{mg}$ olarak yapıldığında 12-24 saat içinde 200-400 mg doz tekrarı yapılabileceği belirtilmiştir ${ }^{4}$.

Tosilizumab kullanılmasının önerilmediği durumlar ise; gebelik ve laktasyon dönemi, toplumsal kökenli pnömoni, aktif hepatit B veya C, aktif akciğer tüberkülozu, HIV enfeksiyonu, bakteriyel ve mantar infeksiyonları, nötropeni $(<500 / \mathrm{mm} 3)$, romatolojik-immün sistem ilișkili hastalıklar, daha önce immün sistemi baskılayan ilaç kullanmış bireyler (kortikosteroidler, anti-sitokin biyolojikler ve immünmodülatörler), alerji ve hipersensitivite varlığı olarak sıralanabilir ${ }^{4,1}$.

Tosilizumab tedavisinde zamanlama önemlidir. Tosilizumabı daha geç alan vakalarda ölüm oranının erken alanlara göre 18 kat daha fazla olduğu saptanmıştır. Tosilizumab kullanımı ile ilgili birçok kriter tanımlanmasına rağmen, hala ilk dozun tam olarak verilme zamanı tartışmalıdır. Tosilizumab tedavisi sonrasında, akut faz yanıtının takibi için serum amiloid $\mathrm{A}$ proteini ya da IL-6 düzeyi kullanılabileceği ve tedavi etkinliğini değerlendirmede inflamasyon bulgularının (ateş, lökosit, CRP, ferritin, vb.) yanı sıra mutlaka hipoksi, solunum yetmezliği, şok ve çoklu organ yetmezliği bulgularının da dikkate alınması gerektiği belirtilmiştir4.
Anakinra: Glikolize olmamış insan IL-1 reseptör antagonistidir. SARS-CoV-2 enfeksiyonu epitelyal hücrelerde ve makrofajlarda bulunan inflamazom NLRP3'ün aktivasyonunu sağlayarak, proinflamatuar sitokinlerden IL-1 $\beta$ ve IL-18 üretimini tetikler, bu da COVID-19 hastalarında ağır semptomların oluşmasında rol oynar. Anakinra IL-1 reseptör antagonisti olarak bu kaskadı kırar.

Anakinra mortaliteyi azaltır. Sağlık Bakanlığı rehberinde, MAS bulguları gelişen hastalarda, Tosilizumab gibi Anakinra da güvenli bir seçenektir. Kısa yarı ömrü (4-6 saat) ve ihtiyaca göre doz $(2-10 \mathrm{mg} / \mathrm{kg})$ ve uygulama yolunu (deri altı ya da intravenöz) ayarlama avantajları daha güvenli bir tedavi olanağı sunabilir. Hastanın klinik bulgularının şiddetine göre günde bir ya da iki kez 100 mg deri altına enjeksiyondan, şiddetli bulgular varlığında günde $3 \mathrm{kez} 200 \mathrm{mg}$ IV uygulamaya kadar doz ayarlaması yapılabilir. Ciddi MAS bulguları olan hastaların ancak yüksek doz İV uygulamalara yanıt verebildiği gözlenmiştir. Anakinra dozu bazı dirençli hastalarda 6 saatte bir $200 \mathrm{mg}$ dozuna çıkılabilir. Yanıt alınan hastalarda günlük doz tedricen düşürülebilir ve ihtiyaca göre gereken dozda kullanımı sürdürülebilir. Tosilizumab gibi doğrudan CRP sentezini engellemediğinden, anakinra tedavisi alan hastalarda CRP akut faz yanıtını takipte güvenli bir test olarak kullanılabilir4.

Kanakinumab: IL-1 $\beta$ 'ya karşı bir insan anti-IL-1 $\beta$ monoklonal antikorudur. Kanakinumab uygulanan COVID-19 hastalarında klinik ve laboratuvara ait parametrelerin düzeldiği farklı çalışmalarla gösterilmiştir. Daha ileri çalışmalara ihtiyaç vardır.

TNF inhibitörleri: TNF inhibitörleri; infliximab, adalimumab, certolizumab, golimumab gibi monoklonal antikorlar veya etanercept, pegsunercept gibi çözünebilir TNF reseptör füzyon proteinleri olarak iki alt gruba ayrilırlar. TNF inhibitörleri pek çok otoimmün ve romatolojik hastalıkta kulanılmaktadır. 
Barisinitib: Romatoid artrit tedavisinde kullanılan bir Janus Kinaz (JAK 1 ve 2) inhibitörüdür. İmmunmodülatör etkisi yanında viral girişe müdahale yoluyla potansiyel antiviral etkilere sahip olduğu düşünülmektedir. ABD'de, FDA, oksijen ve ventilasyon desteği gerektiren Covid-19 hastalarında remdesivir ile kombine olarak kullanılmak üzere (1x4 mg, PO 14 gün) baritinisib için acil kullanım onayı almıştır. $\mathrm{Bu}$ bulgulara karşın barisitinibin COVID-19'da kullanımı için henüz erken olduğu vurgulanmaktadır ve bunun için randomize kontrollü çalışmalara ihtiyaç duyulmaktadır ${ }^{28}$.

Sonuç olarak; Tosilizumabın kortikosteroid ile beraber uygulanması yoğun bakıma gidişi ve invaziv mekanik ventilasyon riskini azaltır. Anti-sitokin tedavilerin kombinasyonları daha etkilidir ve erken dönemde başlanması önemlidir. COVID-19'da antisitokin tedavi için genel öneriler şöyledir; erken dönemde başlanmalı, çoklu anti-sitokin tedavi uygulanmalı, deksametazon zamanında başlanmalı, MAS gelişimi takip edilmeli, sitokin firtınası ve inflamazom aktivasyonu gibi faktörler kontrol edilmeli (örneğin yoğun öksürügün destek tedavisi ile kontrol edilmesi), yaygın/dissemine intravasküler koagülasyon önlenmeli, tedaviye başlanırken çeşitli klinik parametreler (Örneğin CRP, prokalsitonin, ferritin IL-6 seviyesi vd.) dikkate alınmalıdır ${ }^{1}$.

Ruksolitinib (Janus Kinaz inhibitörleri -JAK): Anti-sitokinler yetersiz olduğunda MAS bulguları varlığında Janus Kinaz (JAK) inhibitörleri (ruksolitinib ve diğerleri) de kullanılabilir. IVIg tedavisi de, Ig düzey takibi ile (IgA eksikliğinde kullanılmamalı) genel olarak erişkin hastalarda $20 \mathrm{gr}$ /gün 5 gün olmak üzere önerilmekle birlikte, klinik gereklilik hallerinde toplam doz $2 \mathrm{~g} / \mathrm{kg}$ olacak şekilde 2 gün içinde (1 $\mathrm{g} / \mathrm{kg} / \mathrm{gün})$ ya da 5 gün içerisinde $(0.4 \mathrm{~g} / \mathrm{kg} /$ gün $)$ verilebilir. $2 \mathrm{gr} / \mathrm{kg} / \mathrm{gün}$ dozu ciddi yüklenme bulgularına neden olabilmektedir. Sepsis tablosu ve MAS bulguları açısından yakın takip edilmelidir.

Antikoagülan tedavi: COVID-19'da artmış fibrinojen, D-dimer seviyeleri, uzamış protrombin zamanı (PT) ve aktive parsiyel tromboplastin zamanı (aPTT) ile hafif trombositoz veya trombositopeni nedeni ile hiperkoagülasyon ve artmış tromboz riski vardır. $\mathrm{Bu}$ nedenle COVID-19 nedeniyle hastaneye yatırılan tüm bireyler, kontrendikasyon olmadıkça tromboprofilaksi almalıdır. Düşük moleküler ağırlıklı heparin (DMAH) tercih edilir, ancak DMAH mevcut değilse veya böbrek fonksiyonu ciddi şekilde bozulmuşsa fraksiyone olmayan heparin kullanılabilir. Profilakside oral antikoagulan rutin önerilmemektedir. Çünkü ilaç etkileşimi, böbrek ve karaciğer işlev kusuru ile farmakodinamik etkilenmesi, uzun yarı ömür, maliyet, ve etkisinin geri döndürülmesi için gerekli etken maddelerin her hastanede bulunmaması gerekçe olarak gösterilmektedir.

Terapötik doz (tam doz) antikoagülasyon, COVID-19'u olmayan bireylere benzer şekilde belgelenmiş veya varsayılan VTE için uygundur. Pulmoner anjiyografili bilgisayarlı tomografi veya ventilasyon/ perfüzyon (V/Q) taramasının uygun olmadığı hastalarda tedaviye başlamak için; bacaklarda bilateral kompresyon ultrasonografisi kullanılarak DVT'nin doğrulanması ve transtorasik ekokardiyografi'de ana pulmoner arterde pıhtının görülmesi yeterli olabilir4 .

Profilaktik doz: Enoksaparin 40MG: 4000 antiXa IU/0.4ML. Heparin 25000u/5ML

Ağır dereceli olmayan COVID-19 için doz: BMI $<40 \mathrm{~kg} / \mathrm{m} 2$ : Enoksaparin $40 \mathrm{mg} /$ gün sc. BMI > 40/kg/m2 Enoksaparin 40mg 2x1 sc. Kreatin klirensi < 30ml/dak. ise Enoksaparin kullanılması önerilmez. Standat heparin önerilir. $5000 \mathrm{U}$ sc $2 \mathrm{x} 1$ veya $3 \mathrm{x} 1$.

Ağır dereceli COVID-19 için doz: Kreatin 
klirensi > $30 \mathrm{ml} /$ dak enoxaparin $40 \mathrm{mg} 2 \times 1 \mathrm{sc}$, veya standart heparin $7500 \mathrm{U} / ; 3 \times 1$. İzlem yapılabiliyor ise anti-Xa ile önerilir. D-Dimer yüksekliğinde ( $>2$ kat normal yükseklik) venöz tromboembolizm açısından yüksek risklidir ve $>45$ gün antikoagulan profilaksi önerilmiştir.

Doku plazminojen aktivatörü (tPA) endikasyonları: tPA bir kontrendikasyon olmadığı sürece DVT, masif PE, akut inme, akut miyokard enfarktüsü varlığı gibi olağan endikasyonlar için uygundur.

VTE'si olmayan bireylere hastaneden taburcu olduktan sonra rutin olarak tromboprofilaksi uygulanmaz. Sonuçlara göre yönetimi değiştirmeyeceğinden D-dimer gibi laboratuvar testlerinin de kontrolü önerilmemektedir. VTE öyküsü veya yakın zamanda majör cerrahi veya travma gibi majör protrombotik risk faktörleri olan hastalarda yüksek kanama riski olmadığı sürece taburculuk sonrası tromboprofilaksi önerilmektedir. Taburculuk sonrası VTE riski, COVID-19 dışındaki nedenlerle hastaneye yatış endikasyonlarına benzemektedir ${ }^{28}$.

Ayaktan tedavi gören hastalarda antikoagülasyon uygulanmamakla birlikte, seçilmiş COVID-19'lu bireylerde, özellikle önceki VTE veya yakın zamanda cerrahi, travma veya immobilizasyon gibi diğer trombotik risk faktörlerine sahip olanlarda ayaktan tromboprofilaksi uygun olabilir. Aspirin gibi antiplatelet ajanlar üzerinde çalışılmaktadır, ancak veriler bu ajanların ayaktan hastalarda kullanımını desteklememektedir. Terapötik doz (tam doz) antikoagülasyon, kontrendike olmadığı sürece DVT veya PE tedavisi için uygundur. Tedavi en az 3 ay devam eder.

Kanama, trombozdan daha az görülür ancak oluşabilir. Böyle bir durumda tedavi, COVID-19 olmayan hastalara benzerdir ve transfüzyonları, antikoagülasyonun kesilmesini veya altta yatan kanama bozukluklarına yönelik spesifik ürünlerin verilmesini içerebilir. Antifibrinolitik ajanlar (traneksamik asit, epsilon aminokaproik asit), dengeyi tromboza doğru çevirebilecekleri endişesiyle genellikle kullanılmaz. Bu nedenle, COVID-19 ile ilişkili artmış pıhtılaşma durumunun baskın bulgu olduğu hastalarda bunlardan kaçınılmalıdır. Fibrinojen, COVID-19'da siklıkla artar ve hipofibrinojenemi veya disfibrinojenemiye (fibrinojen aktivite seviyesi $<150$ ila 200 $\mathrm{mg} / \mathrm{dL}$ ) bağlı kanama olmadıkça fibrinojen verilmesi gerekli değildir.

Dipridamol: İn vitro SARS-CoV-2 replikasyonunu azaltmasını gösteren çalışmalar olduğundan antiviral yük azaltma ve antiaggregan antiinflamatuar etki amaçlı $2 \times 75 \mathrm{mg}$ tablet formu hastalığın erken döneminde /inflamasyon döneminde kullanılabilir. Klinik çalışmalarda ilk 14 gün kullanılmıştır, hipotansiyon açısından dikkatli olunmalıdır.

Asetil salisilik asit: COVID-19 hastalarında $100 \mathrm{mg}$ verilmesinin hastalığın akciğer hasarı yapıcı etkisini azalttığını ileri süren kontrol grubu olmayan çalışmalar mevcuttur ancak bunların doğrulanması gerekmektedir.

Sonuç olarak; hastanede yatan COVID-19 hastalarında tromboprofilaksi için, daha yoğun (orta veya terapötik) dozdan ziyade profilaktik doz antikoagülasyon kullanımını önerilir ${ }^{30}$. YBÜ'de yatan şüpheli veya belgelenmiş VTE'si olmayan COVID-19'lu hastalar için de profilaktik doz antikoagülasyon önerilmektedir. D-dimer gibi laboratuvar değerlerindeki izole değişikliklere dayanarak antikoagülasyonda değişiklik yapılması önerilmemektedir. Benzer şekilde, şiddetli COVID-19 tek başına terapötik dozda antikoagülasyon için bir endikasyon değildir.

Vitaminler, çinko, glutatyon, $\mathrm{N}$-asetil sistein ve Kolşisinin COVID-19'dan korunma ve tedavideki yeri: COVID-19'dan korunma ve tedavisinde $\mathrm{C}$ ve $\mathrm{D}$ vitamini ve mineral takviyelerinin, glutatyon, $\mathrm{N}$-asetil sistein ve kolşisinin etkili olup olmadığı ve hangi 
mekanizmayla nasıl yarar sağladıklarına ilişkin yeterli düzeyde bilimsel kanıt yoktur. Ayrıca, COVID-19'dan korunmak amaciyla fazla miktarda alınacak vitaminlere bağlı istenmeyen etkiler ya da toksisite, özellikle yağda çözünen $A, D$ ve $E$ vitaminlerine bağlı olarak, şiddetli olabilir. Normal beslenme ve fizyolojik yollarla vücuda alınabilen bir vitamin ürünü yerine vitamin takviyelerinin kullanılması önerilmemektedir. İyi tasarlanmış ve kanıt derecesi yüksek randomize kontrollü klinik çalışmalara ve meta-analizlere ihtiyaç vardır ${ }^{1}$.

Çıkar Çatışması Beyanı: Yazarlar çıkar çatışması olmadığını bildirmişlerdir.

Finansal Destek: Bu çalışma her hangi bir fon tarafından desteklenmemiştir.

Declaration of ConflictingInterests: The authors declare that they have no conflict of interest.

Financial Disclosure: No financial support was received.

\section{KAYNAKLAR}

1. COVID-19 Tanı ve Tedavisinde Kanıta Dayalı Öneriler ve Türk Toraks Derneği COVID-19 Görev Grubu Görüş Raporu. Editörler: Köktürk N, İtil O. Türk Toraks Derneği COVID-19 E-Kitapları Serisi, Temmuz 2021. ISBN: 978-605-06717-7-3.

2. Akciğer Sağllğı ve Yoğun Bakım Derneği (ASYOD)'un güncel göğüs hastalıkları serisi kitapları, Viral Pnömoniler. Editörler: Bülbül Y, Buruk CK, Diken ÖE. 2021. ISBN: 978-605-9615-655.

3. T.C. Sağlık Bakanlığı COVID-19 (SARS-CoV-2 Enfeksiyonu) Erişkin Hasta Tedavisi. 7 Mayıs 2021. Erişim Adresi: https://covid19.saglik.gov.tr/TR66926/eriskin-hasta-tedavisi.html.

4. T.C. Sağlık Bakanlığı COVID-19 AntisitokinAntiinflamatuar Tedaviler, Koagülopati Yönetimi. 7 Kasım 2020. Erişim Adresi: https://covid19.saglik.gov.tr/TR66341/antisitokin-antiinflamatuar-tedavilerkoagulopati-yonetimi.html
5. T.C. Sağlık Bakanlığ. COVID-19 İmmün (Konvalesan) Plazma Tedarik ve Klinik Kullanımı. Ekim 2020. Erişim Adresi: https://shgmkanhizmetleridb.saglik.gov.tr/Eklenti /39167/0/covid-19-immun-plazma-rehberi-v5.pdf

6. COVID 19 Tedavisinde Kullanılan İlaçlar İle İlgili Hipersensitivite Reaksiyonları. Tepetam M. Akciğer Bülteni. Cilt: 7 • Sayı: 1 • Yll: 2021.

7. Abella BS, Jolkovsky EL, Biney BT, et al; Prevention and Treatment of COVID-19 With Hydroxychloroquine (PATCH) Investigators. Efficacy and Safety of Hydroxychloroquine vs Placebo for Pre-exposure SARS-CoV-2 Prophylaxis Among Health Care Workers: A Randomized Clinical Trial. JAMA Intern Med 2021; 181: 195-202.

8. Ivermectin for Prevention and Treatment of COVID-19 Infection: A Systematic Review, Metaanalysis, and Trial Sequential Analysis to Inform Clinical Guidelines, American Journal of Therapeutics. Bryant, A, Lawrie, TA. Dowswell, T et all. American Journal of Therapeutics: July/ August 2021 - Volume 28 - Issue 4 - p e434-e460. Erişim adresi: $\quad$ https://journals.lww.com/ americantherapeutics/fulltext/2021/08000/iverm ectin_for_prevention_and_treatment_of.aspx.

9. Ivermectin for COVID-19: real-time meta analysis of 65 studies. Covid Analysis, Sep 27, 2021, Version 125 - added Mayer (V1 Nov 26, 2020) [GMK response, Elgazzar]. Erişim adresi: https://ivmmeta.com.

10. Favipiravir Observational Study Group. Preliminary report of the favipiravir observational study in Japan, 2020. Erişim adresi: https://www.kansensho.or.jp/uploads/files/topics /2019ncov/ covid19_casereport_en_200529.pdf.

11. Li Y, Xie W,Lin W, et al. Efficacy and safety of lopinavir/ritonavir or arbidol in adult patients with mild/moderate COVID-19: An exploratory randomized controlled trial. Med (N Y) 2020; 1: 105113.e4. doi: 10.1016/j.medj.2020.04.001.

12. Khalili J S, Zhu H, Mak NSA, Yan Y, Zhu Y. Novel coronavirus treatment with ribavirin: Groundwork for an evaluation concerning COVID-19. J Med Virol. 2020; 92: 740-746.

13. Sean R. Hosein. The promise of molnupiravir. CATIE Canada's source for HIV and Hepatitis C 
information Treatment update 240 March 2021. Erişim adresi: https://www.catie.ca/ en/treatmentupdate/treatmentupdate-240/covid19/promise-molnupiravir.

14. Zangrillo A, Beretta L, Scandroglio AM, et al. Characteristics, treatment, outcomes and cause of death of invasively ventilated patients with COVID19 ARDS in Milan, Italy. Crit Care Resusc 2020 Apr 23. Epub ahead of print. PMID: 32353223.

15. COVID-19 Treatment Guidelines Panel. Coronavirus Disease 2019 (COVID-19) Treatment Guidelines. National Institutes of Health. Updated on 1 Sep, 2020, Erişim adresi: https://www.covid19treatmentguidelines.nih.gov.

16. Getahun H, Smith I, Trivedi K, et al. Tackling antimicrobial resistance in the COVID-19 pandemic. Bulletin of the World Health Organization 2020; 98 : 442-442A.

17. Sieswerda E, de Boer MGJ, Bonten MMJ, et al. Recommendations for antibacterial therapy in adults with COVID-19 an evidence based guideline. Clin Microbiol Infect 2020 Oct 1:S1198743X(20)30594-2.

18. WHO Blood Regulators Network (BRN), "Interim Position Paper on blood regulatory reponse to the evolving out-break of the 2019 novel coronavirus SARS-CoV-2." Erişim adresi: http://www.transfusion.ru/2020/04-03-3.pdf.

19. RECOVERY Collaborative Group. Convalescent plasma in patients admitted to hospital with COVID19 (RECOVERY): a randomised controlled, openlabel, platform trial. Lancet 2021; 397: 2049-59.

20. Gharbharan A, Jordans CCE, Geurtsvankessel C. Convalescent Plasma for COVID-19. A randomized clinical trial. Nature Communiations. (2021) 12: 3189.

21. Libster R, Marc GP, Wappner D. Early High-Titer Plasma Therapy to Prevent Severe Covid-19 in Older Adults. N Engl J Med 2021; 384: 610-8.
22. Cheng Y,Wong $\mathrm{R}$, Soo YO, et al. Use of convalescent plasma therapy in SARS patients in Hong Kong. Eur J Clin Microbiol Infect Dis. 005; 24: 44-6.

23. Recovery Collaborative Group; Horby P, Lim WS, Emberson JR, et al. Dexamethasone in hospitalized patients with Covid-19-preliminary report. N Engl J Med 2021; 384: 693-704.

24. Aveyard P, Gao M, Lindson N, et al. Association between pre-existing respiratory disease and its treatment, and severe COVID-19: a population cohort study. Lancet Respir Med. 2021 Apr 1: S22132600(21)00095-3.

25. Global Initiative for Asthma. Global Strategy for Asthma Management and Prevention, 2021. Erişim adresi: www.ginasthma.org.

26. Kang $\mathrm{S}$, Tanaka $\mathrm{T}$, Inoue $\mathrm{H}$, et al. IL-6 transsignaling induces plasminogen activator inhibitor-1 from vascular endothelial cells in cytokine release syndrome. Proc Natl Acad Sci U S A 2020; 117: 22351-6.

27. Monk PD, Marsden RJ, Tear VJ, et al. Safety and efficacy of inhaled nebulised interferon beta-1a (SNG001) for treatment of SARS-CoV-2 infection: a randomised, double-blind, placebo-controlled, phase 2 trial. Lancet Respir Med 2020; S2213-2600: 30511-7.

28. Roberts LN, Whyte MB, Georgiou L, et al. Postdischarge venous thromboembolism following hospital admission with COVID-19. Blood 2020; 136: $1347-50$.

29. Akima S, McLintock C, Hunt BJ. RE: ISTH interim guidance to recognition and management of coagulopathy in COVID-19. J Thromb Haemost 2020; 18: 2057-8. 